\title{
A STUDY ON SYMBOLS USED IN SO'A PARA ZEDHE CEREMONY
}

\author{
Simplisius Menge Aso (Corresponding Author) \\ Letters Faculty, Kanjuruhan University of Malang \\ J1. S. Supriadi 48 Malang 65148, East Java, Indonesia
}

Phone: (+62) 82302557329 E-mail: symplisiusmengeaso@gmail.com

\author{
Sujito \\ Letters Faculty, Kanjuruhan University of Malang \\ Jl. S. Supriadi 48 Malang 65148, East Java, Indonesia \\ Phone (+62) 8179657789 E-mail: Sujito.team@gmail.com
}

Siane

Letters Faculty, Kanjuruhan University of Malang

J1. S. Supriadi 48 Malang 65148, East Java, Indonesia

Phone (+62) 82141719799 E-mail: Siane.herawati@yahoo.com

\begin{abstract}
So'a is a district where known as one of ethnics group which has many kinds of traditional ceremony. This region is located in the north side of Flores island. There are appear the variety of culture ceremony that certainly inherited from the ancestors. In each of the ceremony appears many kinds of symbol which has a certain meaning related to the human life. One of those is Para Zedhe ceremony. This traditional ceremony is held by some people who want to reach the highest social class and they will be acquainted as Mosalaki. The study was aimed to observe the meaning of symbols used in So'a Para Zedhe ceremony. The research design used descriptive qualitative method. The key instrument of this research was the researcher himself and the tools that used in this research were observation, documentation, and interview and. The analysis of the data included separating all the data that obtained from the sample and also learned the theory. Then, understanding the data and analyzing the meaning of symbols based on the theory. The result of the data analysis revealed the meaning of every symbols used in the ceremony. The symbols meaning that appeared in Para Zedhe ceremony reflected about the existence and So'a society life. Basically, these symbols were represented by the tools, animals, plants, actions, and social life. Mostly, the symbol of animals and plants were often used by people of the tribe in So'a. Moreover, the result showed that in the investigation revealed not only about the symbols, but also the values and functions in society life.
\end{abstract}

Key Words: Symbols, and So'a Para Zedhe Ceremony 


\section{Introduction}

Each country in this world has the different cultures between one to others. As we know that especially in Indonesia, there are many varieties of culture in every region. Culture is also one of crucial aspects for Indonesian life. By the variety of cultures, the people make a good social relationship with a certain society that basis of high tolerance itself. Moreover, the variety of culture in a certain region is quite unique and highly varied. This is because one of the characteristics heritable of culture from old generation to next generation. Culture is a system of human's patterns behavior which generated from social life and it works correlating all of human communities with their environment ecology. The way of life of community in society are consist of technology and economic organization form, settle patterns, form of social grouping and politic organization, belief and religious practice, and so forth. Therefore, it is a fact that all of these can become a heritage because humans perpetuate the culture and being as a continuous ritual to the next generation. According to Condon (1986:3), culture is more than the sum of its part. It is a system of integrated pattern, most of which unconsciously govern human behavior like strings of a puppet control its emotions. Culture refers to various aspects of life that includes ways, attitudes, and beliefs toward something. In other words, culture is learned behavior configuration. Then the behavior supported and passed by members of the society. In this case, the researcher reviews that culture is something may be not aware by the people which govern about human behavior. It is a system of integrated pattern that related to all of aspects and human activities in a certain area. In other words, culture is also defined as the ideas, customs, skills, arts, and tools which characterize a given group of people in a given period of time.

So'a sub district is very incredible and interesting to learn about everything in language and so is the culture. The native speakers produce word, not only in spoken form but also in written form. The people of So'a make a communication among one to another by using So'a language which has own rules, forms and linguistic elements such as morphology, semantics, syntax, and phonology. Moreover, even there is only one village that has a little differets language with others but So'a language still the main basic character. Many things are related to the culture ceremony which have the symbols and also message meaningfully. In this case, by understanding the symbol we will know the meaning of that symbol absolutely. In this study, the researcher would like to observes about Para zedhe ceremony as one of the culture 
ceremonies in So'a district especially on symbols and the meaning of symbols. Here, the researcher wants to learn more and more about semiotics which as a subject learning about meaning on marks, symbols and sign.

In So'a sub district, there is a unique culture ceremony which people called "Para Zedhe ceremony". According to Momersteeg, and Margaretha (1999:17), historically the words of Para $=$ stabbing while Zedhe $=$ celebrate the ceremony. So, Para $=$ Zedhe means that $\mathrm{a}$ ceremony which is performed by individuals for male and female and there are viewers from that village and also from others village. The crucial thing of this ceremony is people who celebrate the ceremony or the owner of the ceremony which people called "Mori Zedhe". Furthermore, the animal that will be killed in this ceremony is "Oa"/"Bhada" (the buffalo) where this activity will become the climax or the end of the ceremony for all that have been passed. Here, the buffalo only as a symbol to ratify those in achieving the perfect place or something like social class. Para Zedhe ceremony has three important parts that should be done by Mori Zedhe. First, they must be a religious person, they must tell the origami of descent, and the last is inheritance division to their children. This ceremony is marked by killing about 5 until 30 buffalos in the middle of the traditional village and the people who perform this ceremony ranging from 5 to 10 persons even it can be more than it. Para Zedhe ceremony is not obligated performed by all of people in So'a region, but it depends on the people who want to do this ceremony.

According to Kroeber and Kluckhohn (1952:357), Culture consists of patterns, explicit and implicit, of and for behavior acquired and transmitted by symbols, constituting the distinctive achievement of human groups, including their embodiment in artifacts; the essential core of culture consists of traditional (i.e. historically derived and selected) ideas and especially their attached values; culture systems may, on the one hand, be considered as products of action, on the other as conditioning elements of further action. In this case, the conception of culture that is given by Kroeber and Kluckhohn indicated that culture is an abstraction or more specifically, "an abstraction from behavior".

There are several reasons why the researcher interested to observes about symbols used in So'a Para Zedhe ceremony. First, the researcher wants to know the symbol because there are many symbol used in this ceremony. Second, the researcher wants to know more specific about 
the symbols meaning which revealed in So'a Para Zedhe ceremony. Third, to know the values are appeared from So'a Para Zedhe ceremony, and increasing the knowledge of the people on cultural especially about Para Zedhe ceremony in So'a sub district. In addition, for the development of So'a culture the researcher will provides all of description about the culture ceremony. Finally, concerning with the reasons and the explanation above the researcher wants to study about the symbols and the meaning of symbols used in So'a Para Zedhe ceremony.

\section{Literature Review}

Generally, the people describe symbol as an object or something that suggests to something else that represents. The symbols are formed by human being in different ways and containing a certain meaning of human life. According to Pickering (1981:69), Symbol is a way of simplifying the complexities of though and experience by hitting upon one thing as representative of many. The symbol may be used as a reminder, a signal, and a call to action. A symbol is also capable of compressing the emotional impact of an over-whelming experience into brief descriptive passage. Based on the perspective above, the researcher defines symbol as a way which planned to make it easier in understanding something by using some representative things. Furthermore, symbol can be used as a signal, an action, gesture, and so forth. In other words, symbol is always has its own meaning which understandable by the people. Then, it can be words, signals, gestures, pictures, or other objects. In every symbol has its own concept either in form of spoken, written, gesture, signals, actions, things, or pictures. In this world, there are so many symbols revealed in each culture ceremony such as wedding ceremony, hunting ceremony, even religious rituals. In short, those are very unique and interesting because of the meaning inside that reflecting all events occurred in human life.

In literature, symbolism is an important device for writers. Literary symbols extend meaning beyond the prosaic representation of realities afforded by literal description or extracted through analysis and exposition. In other words, symbols are educational devices in developing complex ideas to resort to painstaking explanation that would make a story more like an essay than an experience. A symbol is any object or even that has socially come to stand for something else. Symbols are arbitrary stand for actual things. The other definition of symbol given by Fananie (2002:100-102) there are three symbolism words, as follow: (1) Blank symbol, it is a word that expresses a certain symbols and has universal meaning. (2) Natural 
symbol, It is a word in the form of natural reality symbol expressing life. It can be animal life, water, air phenomena and so on. (3) Private symbol, it is a word created specifically by a poet as a symbol to express his unique and style. Based on the comprehension of the three symbolism words given by Fananie, it clarified that a study of the symbol based on its own grouping in order those meaning can be understood well by the readers. Therefore, it will give the different meaning in each symbol observed by the researcher.

Linguistic is knowledge of the languages, which enables combine words to form phrases, and phrases to form sentence. It concludes everything that speakers know about their language such as phonology, semantic, and syntax. One of the branches of linguistic study that can help us to know the meaning is semantics. Because it is one of the branches of linguistic that studies the nature of the meaning of individual word and the meaning words grouped in to phrase and sentences. According to Finocchiaro (1974:177), stated that language is a system of arbitrary vocal symbols which permit all in given culture, or other people who have learned the system of that culture to communicate or to interact. In this case, Finocchiaro said that language is a systematic means of communications ideas or feeling by using conventionalized signs, sounds, gesture, or marks that have understood meaning.

Semiotics is the study of sign processes (semiosis), or signification and communication, signs, and symbols, both individually and grouped into sign systems, including the study of how meaning is constructed and understood. Semioticians often do not restrict themselves to linguistic communication when studying the use of signs but extend the meaning of "sign" to cover all kinds of cultural symbols. Nonetheless, semiotic disciplines closely related to linguistics are studies, discourse, text linguistics, and philosophy of language. Semiotics, within the linguistics paradigm, is the study of the relationship between language and culture. A definition of semiotics given by Alex Sobur (2004:15-16), Semiotics is a science or analytical methods to assess the mark. The signs are the devices that we use in an attempt to fight their way in this world, in the midst of human and human together. Semiotics-or in terms Barthes, semiology-basically want to learn how humanity (humanity) to make sense of things (things). Interpret (to signify) in this case cannot be confused with communicating (to Communicate). Interpret means that the objects are not only carrying information, but also constitute the structured system of signs. Semiotics is closely related to the field of linguistics, which, for its 
part, studies the structure and meaning of language more specifically. The semiotic tradition explores the study of signs and symbols as a significant part of communications.

Culture (from the Latin cultural stemming from colere, meaning "to cultivate,") generally refers to patterns of human activity and the symbolic structures that give such activities significance and importance. Culture can be understood as a system of symbols and meanings that even their creator's contest, that lack fixed boundaries, that are constantly in flux, and that interact and compete which one another. Different definitions of "culture" reflect different theoretical bases on understanding, or criteria for evaluating, and human activity. There is a definition of culture given by Boas (1911/1963:149) stated,"Culture may be defined as the totality of the mental and physical reaction and activities that characterizes the behavior of the individuals composing a social group collectively and individually in relation to their natural environment, to other groups, to members of the group itself and of each individual to himself. It also includes the products of these activities and their role in the life of the groups". From the perspective above, the researcher concludes that culture is the entire of what humans have, what humans do, and what humans change in their social life. By all of these, it is reflecting about humans' habit of civilizing either individually or in a certain social group of people.

\section{Methods}

Basically, a research design is not just a work plan. A work plan details what has to be done to complete the project but the work plan will flow from the project's research design. In this study, the researcher uses a method which is based on the intention of this study. Here, the method that will be adopted in this research is qualitative method and descriptive (ethnography) approach. It is a method that commonly applied in social studies, culture studies and literature studies. Qualitative research is based on a naturalistic research, ethnography research, casus research, and analysis research. It views reality as multilayered, interactive, and a shared social experience interpreted by individuals. Most of description and interpretation are portrayed with words rather than numbers.

\section{Data and Source of the Data}


In this part, the researcher decided to use So'a Para Zedhe ceremony as a subject of this study. To get the data, the researcher would like to make an observation directly to the subject itself. In this subject, the researcher has not known well yet about the process of Para Zedhe ceremony and especially about the symbols and symbols meaning used in this ceremony. Therefore, the researcher would like to observe about the symbols used in So'a Para Zedhe ceremony. Furthermore, as the object in collecting the data, the researcher gets from personal experience, the informants, Mosalaki (a person who really know well about So'a culture), and also from socialite. Here, the researcher hopefully in this observation will accurately obtain the data as validity and reliability as possible.

\section{Technique of Data Collection}

In collecting the accurate data, the researcher necessary uses some of instruments as a technique to obtain the data. These instruments are consists of: (1) Observation. In this analysis, the researcher uses an observation in collecting the data. By doing this way, the researcher directly observes the object of the research in the location itself. So, the observer gets a factual description, accurately and specifically about the situation of an object such as location, geographical, position, the people, livelihood and especially the researcher observes about the way of life, historical, and the culture background of So'a society. (2) Documentation. For this research, the writer uses some ways in getting the data. In this part, the writer reads some books and other references which are concerned with the culture in So'a society specifically about So'a Para Zedhe ceremony. Besides, the writer tries to find out the data in the internet and some documentation in form of pictures and videos which covering about the traditional ceremony of Para Zedhe in So'a sub district, Ngada regency, East Nusa Tenggara province. (3) Interview. In this observation, the observer uses the method of interview to collect the data because it is one of techniques to know the data directly. Furthermore, the research makes an interview in the field directly with the informants to get the accurate data. The informants here are the native of So'a sub district that frequently called "Mosalaki" (they are persons who really understand about So'a cultural knowledge) especially about So'a Para Zedhe ceremony.

\section{Data Analysis}

For this study, the researcher analyzed all the data taken from the result of the observation, interview, and also documentation. Then, after collated the data, the writer takes some steps in 
the data analysis, as follow: (1) Listing the data. (2) Finding some sentences that containing to symbols and then analyzing. (3) Translating the symbols into English. (4) Grouping the symbols based on the steps. (5) Describing the meaning of those symbols. (6) Analyzing the data. (7) Doing triangulation. And the last is (8) Drawing the conclusion for the data analysis.

\section{Triangulation}

In this section, the researcher uses triangulation on his thesis. Triangulation is one of important techniques that used by the researcher to measure whether the data can be trusted or not. In this case, the researcher has to make a communication with other people in comparing notes to extend the researcher's mind. Here, there are a few steps used in this technique to make sure that the data is still valid. Firstly, the researcher watches the video of the ceremony in order the data he collected are appropriate with source. Secondly, the researcher consulted the data with some friends in obtaining more important information to add the researcher knowledge in finishing his analysis. Finally, the researcher discussed the data that he got with Mr. Primus Adhi Bai as a validator from So'a. This is a way for getting the different ideas which useful for an expanding analysis and also to know the validity of the data.

\section{Findings}

Para Zedhe is a ceremony for male and female who want to be a Mosalaki or a famous person in a tribe or village, or people who want to be one of the highest social classes. If someone wants to perform this ceremony, he has to provide animals like buffalo. Para Zedhe ceremony is held once in five or ten years, because it needs a long time in preparing everything such as money, animals especially the buffalo as the important thing of this ceremony and other goods. Actually, the goals of this ceremony are to give what someone has just like meal symbolized from buffalos that will be killed in the middle of the village. After holding the ceremony, therefore when they die, they will be given a sign of sound from bamboo by all people in that village in order their name will always be memorized by everyone at that place. On the other hand, Para Zedhe ceremony is usually performed by a certain persons to shared wealth each other that they have toward the people in a village. 
The people of So'a are really trust of the highest form (Dewa Zeta Nitu Zale) that experienced in the process of cultural life. Besides to the belief in the existence of Dewa Zeta and Nitu Zale, they also have a tremendous awareness of the importance of living together in mutual life. For the people who are capable and wallowing in wealth should be shared to others who lack everything. Therefore, it will be created these same feelings in human beings and respects each other toward fellow the community. In sharing to others, So'a people will perform the traditional rituals which called "Para Zedhe”. This culture ceremony is conducted once in a fairly long period of time is between 5 to 10 years because the people have to make a good preparation and large cost.

\section{The Symbols and the Meaning of Symbols used in So'a Para Zedhe Ceremony.}

Basically, in So'a Para Zedhe ceremony, there are many materials as the symbol which used in this ceremony. Every symbol that revealed in each step of So'a Para Zedhe ceremony has the own meaning.

\section{Utu Tiwo (make an agreement together)}

Utu Tiwo is the first step that should be pasted before the others. This is an activity where the elders and Mosalaki held a discussion and plans in performing the ceremony of Para Zedhe. There are some symbols that used in this part, follows:

- Loka Tua Mata Api: is a symbol of small traditional house like cottage used by the elders to make a discussion in holding the Para Zedhe ceremony itself.

- Watu Lewa: it means a megalith. As a symbol of ancestors' house to give ritual offerings for asking agreement of the ceremony.

- Ti'I Ebu: it means food or ritual offerings that given by the elders to the ancestors.

- Manu: is chicken. As a symbol of animal victim.

- Ha'e: it is a pig. As a symbol of animal victim.

- Ra'a Manu/Ha'e: is blood. It symbols of permission request to the ancestors.

\section{Tata Ngaza (listing of name)}

For the people who are going to perform this ceremony, so it must be listed the entire name of the participants who held Para Zedhe ceremony. Basically, for those (Mori Para) who held this ceremony are the rich man or capable in economic. In this part, the participants make a rituality called "Pati Weti" where they must tell about the treaty to the elders that they would 
be held the ceremony consistently by giving some areca nuts between them and all people who attend at the place. Here, appeared some symbols which are used on this step before the holding of Para Zedhe ceremony, as follow:

- Nika: it means rice. As a symbol of rituality offerings to the ancestors.

- Ate Manu: is chicken's heart as rituality offerings. It symbolizes the strength and peacefulness that given by the ancestors to the participants in holding Para Zedhe ceremony, so it can be running well.

- Nata Heu: means areca nut. It is a symbol of togetherness.

\section{Woro Kazu / Wela Kazu (fire wood)}

This is an activity where families of Mori Para and all people of the village look for the fire wood as preparation toward Para Zedhe ceremony. They take the fire wood from their farms and others place. Here, there are two symbols that used in this activity, as follow:

- Kazu Guru: it means the fire wood of bamboo and symbolizes the braveness.

- Kazu Huma Rogho: is fire wood. It symbolizes of goodness.

\section{Rego Longa (gather in one place)}

Here, the families of Mori Zedhe and all people of the village together make a preparation of food for the ceremony. The symbols are used in this activity, follows:

- Bo: is a small house that used to putt the rice or corn. As a symbol of traditional barn.

- Mama: it means rice. As a symbol of good health and goodness.

- Pangizawa: it means corn. It symbolizes the prosperity.

- Bhada/Oa: it is a buffalo and as a symbol of wealth and capability.

\section{Ngango Wae / Ope Wae (surveying the water location)}

Ngango Wae means to survey the water location. At this activity, the people take the water as the preparation toward the ceremony of Para Zedhe where planned by Mori Ine (an old woman who handles this activity). There are some symbols used in this activity, as follow:

- Mata Wae: it means a water source. As a symbol of good life.

- Po'o: is a bamboo that used to put the water. It is a symbol of social life of the villagers which live together communally. 


\section{Rati T'de (strapped the fence)}

Basically, this is an activity where the people prepare the strong fence as a place or yard to perform the ceremony of Para Zedhe itself. The materials which used in this step, follows:

- T'de: it means fence. It symbolizes the power and safety that protected by the ancestors.

- Ha'e: is a pig. It is a symbol of ritual offerings or animal victim to be held rituality in strapping the fence.

- Manu: it means chicken. As a symbol animal victim.

- Ra'a Manu: it means the blood of chicken. It symbolizes the power of the ancestors in order the performing of Para Zedhe ceremony would be running well and asking for safety to the ancestors in order the fence always be strong.

\section{Pote Fare (the spinning of rope)}

This is an activity in spinning the rope of fiber which held by the elders at Loka Tua Mata Api (a small traditional house made from bamboo). The spinning of rope is done very carefully. This rope fiber is used to strap Bhada/Oa (buffalo) when it drawn to the middle of the village. Actually, the rope fiber is made to avoid the accident or something else which perhaps endanger the viewer or audience who watch this Para Zedhe ceremony. The symbols used are:

- Nao: it means the rope of fiber. As a symbol of the power and togetherness.

- Manu Lalu Bhara: it means a white cock. As animal victim that symbolizes the attendance of the ancestors in the activity of the spinning rope.

- Ha'e: is a pig. It symbols of animal victim.

- Dhea Laka: it means black sticky rice. As a symbol of togetherness and luxurious.

- Lua Manu bhara: is white quill that twined with the fiber rope. It means that the ancestors attend in the rope which used to bind the buffalo in Para Zedhe ceremony.

\section{Tewi Manu (bring chicken)}

In this part, all of family connection and companion bring the chicken to Mori Para (the participants of Para Zedhe ceremony). Here, revealed some symbols, as follow:

- Manu: is chicken. It symbols of animal victim.

- Ra'a Manu: it means chicken's blood. As a symbol of health and safety.

\section{Kobe Lo Rae (the protection night of buffaloes)}


This ceremony is happened in the night where the people protect the buffalo by making some derisory. Usually, the people who protect the buffaloes are friends of Mori Para itself. This activity means that the buffaloes in which they protect would be butchered at tomorrow where known as the day of Para Zedhe ceremony. There are several symbols which used in this step, follows:

- Bhada/Oa: it means buffalo that used as the animal victim. It symbolizes the power, wealth, capability, and social life.

- Ngaza: it means name of the owner or tribe written on the buffalo's body and as a symbol of identity of Mori Para (the participant of Para Zedhe ceremony).

- Tara bheto: is a branch of bamboo that used to hit the buffalo. As a symbol of braveness and virility.

- Perna-Perni: it means small beads suspended on the neck of the buffalo. It symbolizes the riches and luxury of Mori Zedhe (the owner).

\section{Leza Para (the slaughter day of buffaloes)}

This activity is held in the morning before the ceremony of Para Zedhe. Here, the participants doing some rituality toward the slaughter of buffalo.

- Bua Laba: it means dance ceremony. It symbolizes that the slaughter of the buffalo is going to be performed.

- Rogo: is a drum made from bamboo. As a symbol of merry.

- Ka Saka P'te: it means a banquet that held by the participants of Para Zedhe ceremony and surround Nagdhu. As a symbol of togetherness.

- Tua Bhara: it means fermented palm wine. It symbolizes bravery and manliness.

- Nika: is rice that cooked for the banquet of the participants of Para Zedhe ceremony. As a symbol of life and wealth.

- Ate Manu, Nika: it means chicken's heart and rice. Those are symbol of ritual offerings to the ancestors.

- Ngadhu: is a wood like a catapult that located in the middle of the village. It symbolizes the unity of So'a society.

- Ngadhu Ene: as a symbol of mother.

- Ngadhu Ema: is symbol of father.

- Ngadhu Ana: as a symbol of child. 


\section{Para Zedhe (the top of ceremony)}

Basically, Para Zedhe is a top of the ceremony with the steps such as Wi Fare Bhada (get the buffalo), Sa Ngaza (accosting), and Sa Bhea (tell about the descents). The third parts of this activity are held in continued by every participant of Para Zedhe. Here, Wi Fare Bhada is an activity of pulling the buffalo's rope from the house of Mori Para (the owner) to the place of ceremony which done by relative family and friends. There are some symbols, as follow:

- Bhada/Oa: is buffalo that used as the animal victim. It symbols of wealth and capability.

- Sa Ngaza: it means greeting. It symbolizes the greatness and riches.

- Sa Bhea: is tell about the descents of Mori Para (the participant of Para Zedhe ceremony) and only the descent of mother.

- Ughe: means mother of Mori Para. It symbols of fourth descent.

- Ura: is grandmother. As a symbol of third descent.

- Suli: is mother's grandmother. It symbols of second descent.

- Ma: it means grandmother of Mori Para's grandmother. As a symbol of first descent.

- After tell about the descents so, the folks give some gift to Mori Para, follows:

- Zara: it means horse. It symbolizes thanks, honor and perkiness.

- Sapi: is cow. As a symbol of capability, thanks and social life.

- Manu Lalu: it means cock. It symbols of thanks and bravery.

- Tua: is fermented palm wine. It symbolizes the bravery and manliness.

- Anggu: it means wine. It symbols of thanks, manliness, and luxury and also as a symbol of wealth.

- Saka Pu'u: it means people who their ancestors occupy the upper place of Ngadhu. As a symbol of power and greatness.

- Saka Lobo: is people who their ancestors occupy the lower place of Ngadhu. It symbols of simplicity and lowness.

- Laba go: it means gong and bamboo drum. It symbols of merry and gladness.

- Mosa Uma: it means the son of Mori Para (the participant of Para Zedhe) who fixed as the inheritor. It symbolizes the power and prerogative.

- Mosa Ngesu: it means the daughter of Mori Para (the participant of Para Zedhe). As the female, they have no right of the inheritance due to the system of Patrilineal. Therefore, the daughter only gets the praise for everything she done. It symbols of meekness and simplicity. 


\section{T'ge Ulu Bhada (put the buffalo's head)}

This is the last step of Para Zedhe ceremony that called "T'ge Ulu Bhada". Here, the people cook the meat of the buffaloes that already butchered and give it to all family and the people of the village. The head of the buffalo is placed in a tent of bamboo by making the rituality. In holding this rituality, they butchered a pig and chicken as ritual offerings to the ancestors. The symbols are used, as follow:

- Moe Bhada/Oa: it means meat of the buffalo. It symbolizes the life, togetherness and social life.

- Ha'e no'o Manu: it means pig and chicken. As a symbol of animal victim or ritual offering that given by Mori Para to the ancestors.

- Ulu Bhada/Oa: is the buffalo's head. It symbols of heirloom and the ancestors.

- $\boldsymbol{R} \boldsymbol{a}^{\prime} \boldsymbol{a}$ : it is the blood of the animal victim that spattered on horns of the buffalo. It symbolizes that the horns are part of the heirloom things and considered as the ancestors.

- Lua Manu: it means quill which pasted on the horns of the buffalo. This is the symbol of the ancestors.

\section{Discussion}

Culture is a case that always protected and preserved by So'a society and they considered that it is more than gold inheritance by the ancestors. The people of So'a are really appreciated the culture. They ungrudgingly wasted their wealth for holding the culture ceremony. There are many culture ceremonies in So'a sub district such as wedding ceremony, boxing ceremony, hunting ceremony, funeral ceremony, dance ceremony, born ceremony, circumcision ceremony, and Para Zedhe ceremony in which as the main object of this study. Each of the ceremony has a certain meaning and symbols for human life. In this case, Para Zedhe is a ceremony for male and female who want to be a Mosalaki or a famous person in a tribe or village, or people who want to be one of the highest social classes. If someone wants to perform this ceremony, he has to provide animals like buffalo. Para Zedhe ceremony is held once in five or ten years, because it needs a long time in preparing everything such as money, animals especially the buffalo as the important thing of this ceremony and other goods. Actually, the goals of this ceremony are to give what someone has just like meal symbolized from buffalos that will be killed in the middle of the village. After holding the ceremony, therefore when they die, they will be given a sign of sound from bamboo by all people in that village in order their 
name will always be memorized by everyone at that place. On the other hand, Para Zedhe ceremony is usually performed by a certain persons to shared wealth each other that they have toward the people in a village. This ceremony has its own characteristics and values which reflecting all about social life of So'a society.

\section{Conclusion}

In this part, the researcher concludes that Para Zedhe ceremony is the event which shows the significant phases of life for So'a society. The ritual of Para Zedhe is an inheritance that should be protected and preserved, because in this ritual revealed the deepest meaning of the people in the village. This ceremony is rich of the symbolism and terms. Many of the symbols are dominated represented by animals and plants. The purposes of this ritual are firstly, tracing the descendants of the mother until the fourth tier, so that one day their children are not wrong in choosing a wife. This is done because in terms of health as perceived by custom of marry someone who still has a close blood relations can affect to something that is not good for their children later. So, the descent that has been established will be recalled than the brotherhood that has existed ever knowable back. Secondly, dividing the inheritance that given by Mori Para (people who held Para Zedhe ceremony) in front of the people officially. So, everyone can know and as a witness if someday something happened on the legacy that has been distributed. Thirdly, to give each other of the lucky with others people in form of buffalo that is butchered in the middle of the village.

The process of Para Zedhe ceremony is divided into twelve (12) steps that should be passed by Mori Para (people who held the ceremony of Para Zedhe). This ceremony has its own characteristics and values which reflecting all about social life of So'a society. Based on the research of Para Zedhe ceremony, there are many functions and values that are revealed in So'a Para Zedhe ceremony. These are quite influence the existence of So'a society and harmonious relationship between one tribe and others in unity of incredible people. Moreover, by this ritual, Mori Para (people who held this Para Zedhe ceremony) can share the lucky toward others people who are very much to seek. This ceremony has great functions and values for the entire people of So'a.

\section{Suggestion}


In preserving the purity of the culture especially the symbol of Para Zedhe ceremony and values in So'a sub district, therefore the writer suggests to:

(1). The custom figures as the holder of the power of traditional government and all of So'a society in order to keep continue entire the rituals that related to the process of Para Zedhe ceremony purely, in which as a heritage from the ancestors that almost being lost or endangered due to of the developments in science and increasingly rapid of the technological advances.

(2) To the region government of So'a sub district in protecting and preserving the local culture by documenting all custom activities and processes including the traditional ritual of Para Zedhe, because the next generation will probably do not know the things related to the culture ceremony and its meaning. Besides, this documentation is also can be used by others people who are not familiar with So'a culture, so for those who need to know the clearly information specifically about So'a Para Zedhe ceremony will easily to get it.

(3) The government of Ngada regency especially for Department of Education in completing the learning resources of education program in East Nusa Tenggara province. Similarly, the Department of Tourism in developing the tourists area specifically on culture in order can be produced the greatest income for the region government and the prosperity of So'a society in general.

(4) For the other readers.

As suitable with the explanation above, the researcher considers that this study is new at Kanjuruhan University of Malang in the language field especially for English Literature. Here, the researcher suggests that this study can give a description as the information to the readers about the symbols which are used in So'a Para Zedhe ceremony. There are many kinds of culture ceremony in So'a sub district. So, as the researcher, hopefully that others student who want to analyze the culture ceremony of So'a can use this thesis for guidance to the next analysis but in different aspects. Besides of So'a Para Zedhe ceremony, the others researcher can learn more about wedding ceremony, dance ceremony, funeral ceremony, hunting ceremony, boxing ceremony, circumcision ceremony, born ceremony, pregnant ceremony process, and so forth. Moreover, the researcher suggests that if the readers who wish to analyze So'a Para Zedhe ceremony perhaps can add the theory taken from other sources which are not included in this thesis. Then, the researcher hopes that all student of Kanjuruhan University of Malang especially the students from So'a sub district are interested to study the ceremony of 
Para Zedhe in So'a, specifically for literary devices that revealed in So'a Para Zedhe ceremony.

\section{REFERENCES}

Boas, F. (1963). The Mind of Primitive Man. New York: The Free Press.

Condon, J. (1975). An Introduction to Intercultural Communication. Indianapolis: BobbsMerril.

Fananie, Z. (2002). Telaah Sastra. Surakarta: Universitas Muhamadiah.

Finocchiaro, M. (1989). English as a Second/ Foreign Language: from Theory to Practice. Englewood Cliffs, N. J: Practice Hall Regents.

Kroeber, A and Clyde K. (1952). Culture: a critical review of concepts and definitions. Cambridge: Museum of Archaeology and Ethnology.

Mommersteeg, A and Margaretha D. (1999). Punu Nange': Ceritera dari So 'a, Flores. Jakarta: Yayasan Obor Indonesia dan Yayasan Asosiasi Tradisi Lisan (ATL).

Pickering, J and Hoeper J. (1997). Literature (Fifth Edition). New Jersey: Prentice Hall.

Sobur, A. (2004). Semiotika Komunikasi, Bandung: Remaja Rosdakarya. 